\title{
Peran Dukungan Sosial dan Job Insecurity Terhadap Peningkatan Kinerja Karyawan Hotel di Tengah Pandemi Covid-19
}

\author{
${ }^{1}$ Shella Farhatul Azizah, ${ }^{2}$ Acep Samsudin, ${ }^{3}$ Asep Muhamad Ramdan \\ Universitas Muhammadiyah Sukabumi, Kota Sukabumi, Jawa Barat \\ Email : ${ }^{1}$ shellafa062@ummi.ac.id
}

(Diterima: Juli 2021; Direvisi: Juli 2021; Dipublikasikan: September 2021)

\begin{abstract}
ABSTRAK
Kinerja karyawan di masa pandemi Covid-19 menarik perhatian peneliti untuk mengkaji bidang ini. Hal ini dikarenakan maraknya perbincangan mengenai pandemi Covid-19 di dua tahun terakhir. Tujuan pada penelitian ini adalah untuk mengetahui pengaruh dukungan sosial dan job insecurity terhadap kinerja karyawan hotel. Metode yang digunakan adalah metode deskriptif dan asosiatif dengan pendekatan kuantitatif. Subjek penelitiannya adalah karyawan Hotel X Sukabumi. Teknik sampling yang digunakan adalah teknik sampling jenuh dengan sampel sebanyak 75 responden. Pengumpulan data menggunakan wawancara, kuesioner, observasi, dokumentasi dan studi kepustakaan. Analisis data menggunakan analisis koefisien korelasi, analisis koefisien determinasi, analisis regresi linear berganda, uji model penelitian dan uji hipotesis penelitian. Hasil penelitian menunjukkan nilai t hitung untuk variabel dukungan sosial terhadap kinerja karyawan adalah 3,158 > 1,99 dan nilai signifikan 0,002 < 0,05 disimpulkan bahwa dukungan sosial memiliki pengaruh yang signifikan terhadap kinerja karyawan. Nilai t hitung untuk variabel job insecurity terhadap kinerja karyawan adalah 2,750 > 1,99 dan nilai signifikansi 0,008<0,05 disimpulkan bahwa job insecurity memiliki pengaruh yang signifikan terhadap kinerja karyawan.
\end{abstract}

\section{Kata Kunci: Dukungan Sosial, Job Insecurity, Kinerja Karyawan}




\section{PENDAHULUAN}

Pandemi Corona Virus Desease (Covid-19) menjadi suatu fenomena serius yang gencar diperbincangkan saat ini. Virus yang berasal dari Wuhan China ini menyebabkan perubahan besar bagi seluruh aspek kehidupan, yang mana pandemi ini menyebabkan kesehatan manusia menjadi terganggu, kerugian bagi perekonomian, pendidikan dan lainlainnya (Shabuur \& Mangundjaya, 2020). Masyarakat dihimbau untuk menerapkan protokol kesehatan dan melakukan PSBB (Pembatasan Sosial Berskala Besar) dimanapun berada, hal tersebut dilakukan guna mencegah penyebaran virus tersebut (Kominfo, 2020).

Di masa pandemi Covid-19 ini, banyaknya sektor-sektor yang terkena dampaknya, diantaranya seperti akomodasi perhotelan, transportasi, taman hiburan dan lain-lain. Industri perhotelan merupakan salah satu yang paling terpuruk, banyaknya hotel yang berhenti beroperasi selama beberapa waktu untuk mencegah penyebaran virus tersebut (Alinea.id, 2020). Sehingga perusahaan terpaksa harus merumahkan karyawannya, bahkan ada pula perusahaan yang melakukan PHK (Pemutusan Hubungan Kerja) terhadap karyawannya, dikarenakan pemasukan perusahaan yang tidak stabil dan cenderung menurun (Muslim, 2020b).

Suatu perusahaan tidak terlepas dari peranan sumber daya manusia, maka dari itu perusahaan harus selalu berusaha melakukan yang terbaik

demi kelangsungan perusahaan di masa pandemi Covid-19 (Bulgis et al., 2021). Sumber daya manusia yang baik sangat membantu perusahaan dalam mencapai tujuan, sehingga penting bagi perusahaan untuk memelihara sumber daya manusia. Dengan memelihara sumber daya manusia yang baik maka karyawan akan menghasilkan kinerja yang optimal (Anggraeni et al., 2020).

Di masa pandemi Covid-19 saat ini, menjaga produktivitas kinerja sangatlah sulit, sehingga timbulah permasalahan-permasalahan yang berkaitan dengan kinerja karyawan diantaranya tidak disiplin dalam menerapkan protokol kesehatan, kualitas kerja dan efisiensi yang sulit dikontrol (Susanti et al., 2021).

Adapun

penyebab permasalahan yang sering terjadi pada sumber daya manusia di masa pandemi Covid-19 diantaranya kurangnya motivasi (Susanti et al., 2021), stress kerja, banyaknya karyawan yang terkena PHK, kekhawatiran melakukan aktivitas, kecemasan yang berpengaruh terhadap psikis seseorang, dan ketidakpastian situasi (Muslim, 2020a).

Berdasarkan permasalahan yang terjadi, maka dari itu peneliti tertarik untuk meneliti dengan judul "Peran Dukungan Sosial dan Job Insecurity Terhadap Peningkatan 
Kinerja Karyawan Hotel di Tengah Pandemi Covid-19".

\section{TINJAUAN PUSTAKA}

\section{Dukungan Sosial}

Dukungan sosial merupakan suatu bentuk kepedulian yang diterima dari seseorang, yang mana terdapat hubungan sosial yang baik, sehingga mampu memberikan perubahan yang lebih baik (Achmad \& Yuniawan, 2018). Sedangkan menurut Wulandari \& Lestari (2018) dukungan sosial merupakan suatu dorongan semangat yang berasal dari orang-orang terdekat yang dapat memberikan kenyamanan psikologis.

Adapun dimensi dukungan sosial yang dikemukakan oleh Safarino (dalam Suyuthi, 2019) yaitu 1) Dukungan instrumental, 2) Dukungan informasional, 3) Dukungan emosional, dan 4) Penilaian positif. Sedangkan menurut Eni \& Herdiyanto (2018) dimensi dukungan sosial yaitu 1) Dukungan pendampingan 2) Dukungan emosional 3) Dukungan instrumental 4) Dukungan kelompok atau persahabatan 5) Dukungan informasi. Dalam penelitian ini, peneliti menggunakan dimensi dukungan emosional, dukungan penghargaan, dukungan instrumental dan dukungan informal.

Penelitian terdahulu yang dilakukan oleh Adnyaswari \& Adnyani (2017) menyatakan bahwa dukungan sosial terhadap kinerja karyawan berpengaruh positif dan signifikan. Sedangkan menurut Ramadhani (2019) dukungan sosial terhadap kinerja karyawan tidak berpengaruh.

\section{Job Insecurity}

$\mathrm{Job}$ Insecurity merupakan suatu kondisi ketidakpastian akan pekerjaannya, yang menyebabkan suatu karyawan menjadi bingung terhadap pekerjaanya dalam situasi dan kodisi yang dijalaninya saat ini (Triyono et al., 2020) Sedangkan menurut Mashudi et al. (2020) job insecurity merupakan rasa tidak aman dan cemas akan pekerjaan di masa yang akan datang.

Adapun dimensi job insecurity yang dijelaskan oleh Rasip et al., (2020) yaitu 1) aspek pekerjaan 2) total pekerjaan 3) ketidakberdayaan Sedangkan menurut Triyono et al., (2020) yaitu 1) pentingnya faktor pekerjaan 2) pentingnya kejadian pekerjaan 3) kemampuan individu untuk mengendalikan perubahan. Dalam penelitian ini, peneliti menggunakan dimensi aspek pekerjaan, total pekerjaan, dan kemampuan individu untuk mengendalkan perubahan.

Penelitian terdahulu yang dilakukan oleh Nasution (2020) menyatakan bahwa job insecurity terhadap kinerja karyawan berpengaruh positif dan signifikan. Sedangkan menurut Murni \& Yurnalis (2018) job insecurity terhadap kinerja karyawan berpengaruh negatif dan signifikan.

H2 : Ketidakamanan Kerja berpengaruh terhadap Kinerja Karyawan 


\section{Kinerja Karyawan}

Kinerja merupakan suatu hasil kerja yang dilakukan seseorang atau kelompok selama periode tertentu (Wartono, 2017). Sedangkan menurut Muzzaki et al. (2016) kinerja merupakan suatu kemampuan seseorang dalam mencapai persyaratan pekerjaan, sehingga target dapat tercapai tepat waktu dan sesuai dengan tujuan yang ditetapkan perusahaan.

Adapun dimensi kinerja karyawan yang diterangkan oleh Suzana (2017) diantaranya 1) sifat 2) perilaku 3) kompetensi 4) pencapaian tujuan 5) potensi perbaikan. Menurut Setiawan (2015) dimensi kinerja yaitu 1) hasil kerja, 2) kompetensi kerja, dan 3) efektifitas pribadi. Menurut Lewiuci \& Mustamu (2016) dimensi kinerja yaitu 1) kualitas, 2) kuantitas, 3) pelaksanaan tugas, dan 4) tanggung jawab. Dalam penelitian ini, peneliti menggunakan dimensi hasil kerja, perilaku, pelaksanaan tugas dan tanggung jawab.

\section{METODE PENELITIAN}

Pendekatan kuantitatif dengan metode deskriptif dan asosiatif. Populasi dalam penelitian ini adalah karyawan hotel X Sukabumi dengan anggota sebanyak 75 orang. Sampel dalam penelitian ini menggunakan sampel jenuh sehingga sampel didapat 75 orang. Teknik pengumpulan data menggunakan data primer dan sekunder. Data primer diataranya non-participant observation, wawancara tidak terstruktur dan kuesioner semantic differensial. Data sekunder diantaranya studi kepustakaan dan dokumentasi.

Peneliti menggunakan software IBM SPSS versi 24. Adapun teknik analisis data dalam penelitian ini pengujian validitas, pengujian reliabilitas, pengujian normalitas, koefisien korelasi, koefisien determinasi, regresi linear berganda, pengujian model penelitian (uji F), dan pengujian hipotesis penelitian (uji t).

\section{HASIL PENELITIAN}

\section{Uji Validitas dan Reliabilitas}

Tabel 1. Pengujian Validitas dan Reliabilitas

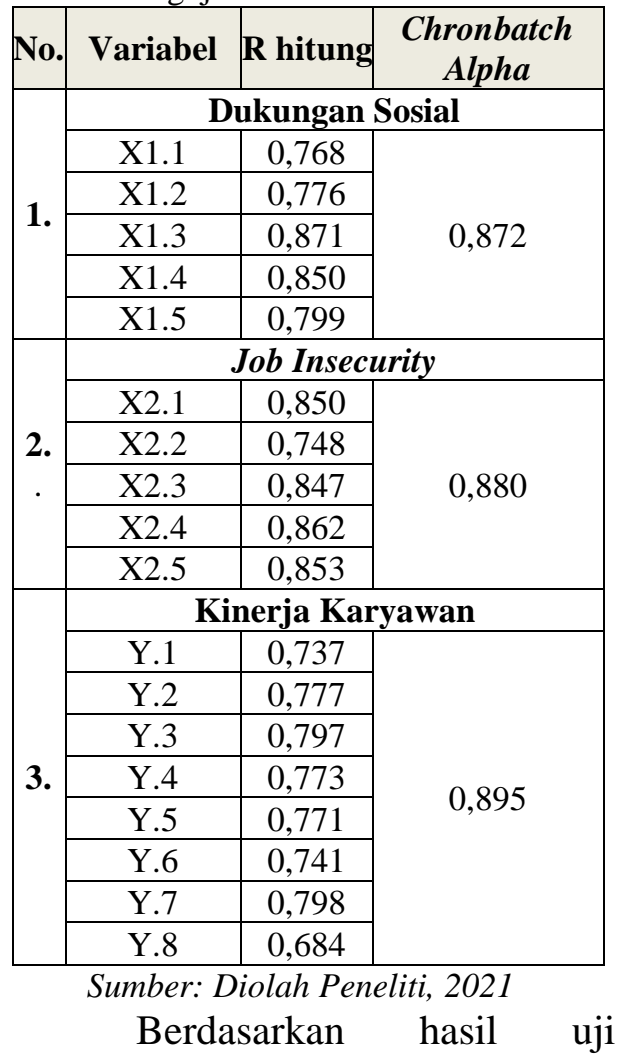
validitas dan reliabilitas diatas, pada tabel uji validitas masingmasing item memiliki nilai $r$ hitung lebih besar dari $r$ kritis 0,3 maka seluruh item dapat dinyatakan valid. Sedangkan pada tabel uji reliabilitas, masingmasing variabel memiliki nilai 
Cronbach Alpha lebih besar dari $\mathrm{r}$

dinyatakan reliabel

kritis 0,6 maka seluruhnya dapat

2. Analisis Koefisien Korelasi

Tabel 2.

Model Summary ${ }^{\mathrm{b}}$

\begin{tabular}{l|ccr} 
Model R & R Square & Adjusted R Square & Std. Error of the Estimate \\
\hline $1 . .800^{\mathrm{a}}$ & .640 & .630 & 3.49656 \\
\hline Sumber: Diolah Peneliti, 2021
\end{tabular}

Berdasarkan tabel di atas, diperoleh nilai koefisien korelasi (R) sebesar 0,800, maka dapat disimpulkan bahwa Dukungan Sosial dan Job Insecurity memiliki tingkat kekuatan pengaruh yang sangat kuat terhadap kinerja karyawan (Y). Sedangkan nilai koefisien determinasi $\left(\mathrm{R}^{2}\right)$ sebesar 64\% yang berarti bahwa pengaruh dukungan sosial dan job insecurity terhadap kinerja karyawan sebesar $64 \%$ sedangkan sisanya sebesar $36 \%$ dipengaruhi oleh faktor diluar penelitian ini.

\section{Analisis Regresi Linear Berganda}

\begin{tabular}{|c|c|c|c|c|c|}
\hline \multirow[b]{3}{*}{ Model } & \multicolumn{3}{|c|}{$\begin{array}{c}\text { Tabel } 3 . \\
\text { Coefficients }^{\mathbf{a}}\end{array}$} & \multirow[b]{3}{*}{$\mathrm{t}$} & \multirow[b]{3}{*}{ Sig. } \\
\hline & \multicolumn{2}{|c|}{$\begin{array}{l}\text { Unstandardized } \\
\text { Coefficients }\end{array}$} & \multirow{2}{*}{$\begin{array}{c}\text { Standardized Coefficients } \\
\text { Beta }\end{array}$} & & \\
\hline & $\mathrm{B}$ & Std. Error & & & \\
\hline 1 (Constant) & 6.743 & 2.2 & & 3.032 & .003 \\
\hline $\mathrm{X} 1$ & .659 & .2 & .44 & 3.158 & .002 \\
\hline $\mathrm{X} 2$ & .630 & .2 & .38 & 2.750 & .008 \\
\hline
\end{tabular}

Sumber: Diolah Peneliti, 2021

Berdasarkan pada tabel di atas, diperoleh persamaan regresi linier berganda dalam penelitian ini adalah: $\mathrm{Y}=6,743+0,659 \mathrm{X}_{1}+$ $0,630 \mathrm{X}_{2}$

\section{Analisis Model Penelitian (Uji F)}

Tabel 4.

ANOVA $^{a}$

\begin{tabular}{lr|r|r|r|r} 
Model & Sum of Squares & df & Mean Square & F & Sig. \\
\hline 1 Regression & 1563.252 & 2 & 781.626 & 63.932 & $.000^{\mathrm{b}}$ \\
\hline Residual & 880.268 & 72 & 12.226 & & \\
\hline Total & 2443.520 & 74 & & & \\
\hline
\end{tabular}

Sumber: Diolah Peneliti, 2021

Tabel diatas menjelaskan bahwa Fhitung $=63,932$ dan memiliki tingkat signifikansi $0,000<0,05$. Maka dari itu $\mathrm{F}_{\text {hitung }}>\mathrm{F}_{\text {tabel }}$ yaitu 63,932 $>3,12$. Artinya bahwa Dukungan Sosial dan Job Insecurity layak dalam menjelaskan pengaruhnya terhadap Kinerja Karyawan

5. Analisis Hipotesis Penelitian (Uji t)

Tabel 4.5

Coefficients $^{\mathrm{a}}$

\begin{tabular}{|c|c|c|c|c|c|}
\hline \multirow[b]{3}{*}{ Model } & \multicolumn{3}{|c|}{ Coefficients $^{\mathbf{a}}$} & \multirow[b]{3}{*}{$\mathrm{t}$} & \multirow[b]{3}{*}{ Sig. } \\
\hline & \multicolumn{2}{|c|}{ Unstandardized Coefficients } & $\begin{array}{c}\text { Standardized } \\
\text { Coefficients }\end{array}$ & & \\
\hline & $\mathrm{B}$ & Std. Error & Beta & & \\
\hline 1 (Constant) & & 2.224 & & 3.032 & .003 \\
\hline
\end{tabular}




\begin{tabular}{llllll}
$\mathrm{X} 1$ & .659 & .209 & .443 & 3.158 & .002 \\
\hline $\mathrm{X} 2$ & .630 & .229 & .386 & 2.750 & .008 \\
\hline
\end{tabular}

Sumber: Diolah Peneliti, 2021

Tabel diatas menjelaskan bahwa variabel dukungan sosial (X1) diperoleh nilai $t_{\text {hitung }}=3,158$ dengan taraf signifikansi $0,002<$ 0,05 . Maka $t_{\text {hitung }}>t_{\text {tabel }}=3,158>$ 1,99 yang berarti Ha diterima dan Ho ditolak. Dengan ini berarti bahwa dukungan sosial berpengaruh positif dan signifikan terhadap kinerja karyawan secara parsial.

Sedangkan variabel job insecurity (X2) diperoleh nilai $t_{\text {hitung }}=2,750$ dengan taraf signifikansi $0,008<0,05$. Maka $t_{\text {hitung }}>\mathrm{t}_{\text {tabel }}=2,750>1,99$ yang berarti Ha diterima dan Ho ditolak. Dengan ini berarti bahwa job insecurity berpengaruh positif dan signifikan terhadap kinerja karyawan secara parsial.

\section{PEMBAHASAN}

\section{Dukungan Sosial berpengaruh} terhadap Kinerja Karyawan

Hasil penelitian ini menunjukkan bahwa variabel Dukungan Sosial hasilnya memiliki $\mathrm{t}$ hitung $>\mathrm{t}$ tabel yaitu 3,158 >1,99, dan signifikansi $0,002<0,05$. Artinya terdapat pengaruh yang positif dan signifikan antara dukungan sosial terhadap kinerja karyawan. Hasil penelitian ini selaras dengan penelitian Adnyaswari \& Adnyani (2017) yang berjudul Pengaruh Dukungan Sosial dan Burnout Terhadap Kinerja Perawat Rawat Inap RSUP Sanglah yang menyatakan bahwa terdapat pengaruh yang positif dan signifikan antara dukungan sosial terhadap kinerja karyawan.

Job Insecurity berpengaruh terhadap Kinerja Karyawan

Hasil penelitian ini menunjukkan bahwa variabel $J o b$ Insecurity hasilnya memiliki $\mathrm{t}$ hitung $>\mathrm{t}$ tabel yaitu 2,750 > 1,99, dan signifikansi $0,008<0,05$. Artinya terdapat pengaruh yang positif dan signifikan antara job insecurity terhadap kinerja karyawan. Hasil penelitian ini selaras dengan penelitian Nasution (2020) yang berjudul Pengaruh Job Insecurity, Fasilitas Kerja dan Karakteristik Individu terhadap Prestasi Kinerja Pegawai Puskesmas Bromo Medan yang menyatakan bahwa terdapat pengaruh yang positif dan signifikan antara job insecurity terhadap kinerja karyawan.

\section{KESIMPULAN DAN SARAN Kesimpulan}

Berdasarkan analisis yang telah dilakukan, peneliti akan memberikan kesimpulan untuk menjawab tujuan pada penelitian ini. Dukungan sosial dan job insecurity pada karyawan Hotel X Sukabumi sudah cukup baik, namun masih ada faktor-faktor lain masih perlu diperhatikan guna meningkatkan kinerja karyawan. Hasil dari koefisien determinasi $\left(\mathrm{R}^{2}\right)$ dijelaskan bahwa persentase kontribusi dukungan sosial dan job insecurity terhadap kinerja karyawan sebesar $64 \%$, dan sisanya $36 \%$ dari variabel lain. Hasil uji hipotesis menjelaskan bahwa dukungan sosial 
dan job insecurity berpengaruh positif dan signifikan terhadap kinerja karyawan.

\section{Saran}

Berdasarkan kesimpulan diatas, Hotel X Sukabumi harus lebih memperhatikan dukungan sosial dan job insecurity karyawan, guna meningkatkan kinerja karyawan. Untuk penelitian selanjutnya disarankan untuk menggunakan subjek yang lebih luas lagi.

\section{DAFTAR PUSTAKA}

Achmad, A. W., \& Yuniawan, A. (2018). Analisis Efek Dukungan Sosial, Budaya Organisasi, dan Kohesivitas Karyawan Terhadap Loyalitas Karyawan.

Diponegoro Journal of Management, 7(4), 1-13.

Adnyaswari, N. A., \& Adnyani, I. G. A. D. (2017). Pengaruh Dukungan Sosial dan Burnout Terhadap Kinerja Perawat Rawat Inap RSUP Sanglah. EJurnal Manajemen Universitas Udayana, 6(5), 2474-2500.

Alinea.id. (2020). 6 Sektor Ini Terdampak Paling Parah Akibat Covid-19. Alinea.Id. https://www.alinea.id/bisnis/6sektor-ini-terdampak-palingparah-akibat-covid-19b1ZQh9v3C

Anggraeni, D. N., Samsudin, A., \& Sunarya, E. (2020). Penerapan Pendidikan dan Pengembangan Karir Terhadap Kinerja Karyawan PT. Indomarco Sukabumi. Ekuitas: Jurnal Pendidikan Ekonomi, 8(2), 203210.

Bulgis, Djaelani, A. Q., \& Khalikussabir. (2021). Pengaruh
Inovasi, Kreativitas dan Semangat Kerja Terhadap Kinerja Karyawan pada Masa Pandemi Covid-19 pada UPTD Peternakan Kec. Woja Dompu. E-Jurnal Riset Manajemen, 10(13), 121-131.

Eni, K. Y., \& Herdiyanto, Y. K. (2018). Dukungan Sosial Keluarga terhadap Pemulihan Orang dengan Skizofrenia (ODS) di Bali. Jurnal Psikologi Udayana, 5(2), 268-281.

Kominfo. (2020). Disiplin 3M, Kunci Utama Tekan Penularan Covid$19 . \quad$ Kominfo.Go.Id. https://kominfo.go.id/content/de tail/29899/disiplin-3m-kunciutama-tekan-penularan-covid19/0/sorotan media

Lewiuci, P. G., \& Mustamu, R. H. (2016). Pengaruh Employee Engagement terhadap Kinerja Karyawan pada Perusahaan Keluarga Produsen Senapan Angin. Agora Journal, 4(2), 101-107.

Mashudi, Pramesti, Z. H., \& Kholidin. (2020). Pengaruh Komitmen Organisasi dan Job Insecurity Terhadap Kinerja Karyawan di PAM Tirta Moedal Kota. SENABISMA, 6, 47-59.

Murni, S., \& Yurnalis. (2018). Pengaruh Job Insecurity Terhadap Kesejahteraan dan Kinerja Karyawan Kontrak Pada Kantor Pusat Administrasi Universitas Syiah Kuala Banda Aceh. Jurnal Ilmiah Mahasiswa Ekonomi Manajemen, 3(4), 7789.

Muslim, M. (2020a). Manajemen Stress Pada Masa Pandemi Covid-19. ESENSI: Jurnal 
Manajemen Bisnis, 23(2), 192201.

Muslim, M. (2020b). PHK Pada Masa Pandemi Covid-19. ESENSI: Jurnal Manajemen Bisnis, 23(3), 357-370.

Muzzaki, M. H., Susilo, H., \& Yuniarto, S. R. (2016). Pengaruh Penggunaan Teknologi Informasi Terhadap Kinerja Karyawan. Jurnal Administrasi Bisnis (JAB), 39(2), 169-175.

Nasution, N. (2020). Pengaruh Job Insecurity, Fasilitas Kerja dan Karakteristik Individu terhadap Prestasi Kinerja Pegawai Puskesmas Bromo Medan. Tijarah, 2(20), 54-62.

Ramadhani, F. A. (2019). Pengaruh Dukungan Sosial dan Gaya Kepemimpinan Partisipatif terhadap Kinerja Karyawan pada Divisi Pemasaran PDAM Surya Sembada Kota Surabaya. Jurnal Ilmu Manajemen, 7(2), 410-418. Rasip, A., Kurniawan, H., \& Syahrina, I. A. (2020). Hubungan Antara Job Insecurity Dengan Burnout Pada Karyawan Outsourching Fifgroup Cabang Padang. Psyche 165 Journal, 13(2), 140-146.

Setiawan, K. C. (2015). Pengaruh Iklim Organisasi Terhadap Kinerja Karyawan Level Pelaksana di Divisi Operasi PT. Pusri Palembang. Jurnal Psikologi Islami, 1(1), 23-32.

Shabuur, M. I., \& Mangundjaya, W. L. (2020). Pengelolaan Stres dan Peningkatan Produktivitas Kerja Selama Work From Home Pada Masa Pandemi Covid-19. Jurnal Psikologi Udayana, 7(2), 93109.
Susanti, R., Amelia, D. T., Damaiyana, F., \& Santoso, O. R. B. (2021). Produktivitas Kerja Saat Work From Home (WFH) dan Work From Office (WFO) pada Dosen FKM Universitas Mulawarman di Masa Pandemi Covid-19. Jurnal Ilmiah Kesehatan Masyarakat, 13, 2833.

Suyuthi, N. F. (2019). Dukungan Sosial Terhadap Kinerja Usaha IWAPI Provinsi Sulawesi Selatan. Jurnal Manajemen Dan Organisasi Review (MANOR), 1(1), 35-44.

Suzana, A. (2017). Pengaruh Organizational Citizenship Behavior (OCB) Terhadap Kinerja Karyawan. Jurnal Logika, xix(1), 42-50.

Triyono, S., Wahyudi, I., \& Harahap, D. H. (2020). Hubungan Job Insecurity dan Job Satisfaction pada Karyawan Outsourcing di PT. X. Jurnal Psikologi, 16(1), 25-35.

Wartono, T. (2017). Pengaruh Stres Kerja Terhadap Kinerja Karyawan (Studi Pada Karyawan Majalah Mother and Baby). Jurnal Ilmiah Prodi Manajemen Universitas Pamulang, 4(2), 41-55.

Wulandari, P. D., \& Lestari, M. D. (2018). Pengaruh Penerimaan Diri Pada Kondisi Pensiun dan Dukungan Sosial Terhadap Kecemasan Menghadapi Masa Pensiun Pada Pegawai Negeri Sipil di Kabupaten Badung. Jurnal Psikologi Udayana, 8799. 